\title{
Short communication: Pheromonicin-SA affects mRNA expression of toll-like receptors, cytokines, and lactoferrin by Staphylococcus aureus-infected bovine mammary epithelial cells
}

\author{
Y. H. Zhu, ${ }^{, 1}$ P. Q. Liu, ${ }^{\star 1}$ X. G. Weng, ${ }^{,}$Z. Y. Zhuge, ${ }^{\star}$ R. Zhang, ${ }^{*}$ J. L. Ma, ${ }^{\star}$ X. Q. Qiu,† R. Q. Li, \\ X. L. Zhang,‡ and J. F. Wang ${ }^{\star 2}$ \\ ${ }^{*}$ College of Veterinary Medicine, China Agricultural University, Beijing 100193, China \\ †Laboratory of Transplant Engineering and Immunology, Sichuan University, Chengdu 610041, China \\ ¥Beijing Created Biotechnology Co. Ltd., Beijing 100080, China
}

\begin{abstract}
Pheromonicin-SA (Ph-SA) is a newly developed, engineered multidomain peptide that has a bactericidal effect against Staphylococcus aureus. The objective of this study was to characterize innate immune responses by Staph. aureus-stimulated bovine mammary epithelial cells (BMEC) following treatment with Ph-SA. Primary BMEC from one lactating Holstein cow were isolated and exposed to Staph. aureus for $2 \mathrm{~h}$, and then treated with rifampicin or Ph-SA. Total RNA was isolated from BMEC at $0,2,6,12$, and $24 \mathrm{~h}$ postinfection, and the mRNA expression of selected genes, including toll-like receptor (TLR)2 and TLR4, IL-1 $\beta$, IL-6, IL-8, tumor necrosis factor $\alpha(\mathrm{TNF}-\alpha)$, and lactoferrin, was quantified by real-time PCR. In the rifampicin group, increases in the expression of mRNA for TNF- $\alpha$, IL$1 \beta$, IL-6, IL-8, and lactoferrin were observed at $6 \mathrm{~h}$ postinfection and in the expression of mRNA for TLR2 but not for TLR4 at $12 \mathrm{~h}$ postinfection. In the Ph-SA group, increases in the mRNA expression of TLR2, TNF- $\alpha$, IL-1 $\beta$, IL-6, IL-8, and lactoferrin were observed at $6 \mathrm{~h}$ postinfection, and an increase in TLR4 mRNA expression was observed at $24 \mathrm{~h}$ postinfection. At $24 \mathrm{~h}$ postinfection, the mRNA expression of TLR4, TNF- $\alpha$, IL-1 $\beta$, IL-6, IL-8, and lactoferrin was higher in the Ph-SA group than in the rifampicin group. In conclusion, Ph-SA might promote the expression of mRNA for TLR2, TLR4, the pro-inflammatory cytokines IL1, IL-6, and TNF- $\alpha$, the chemotactic factor IL-8, and lactoferrin in Staph. aureus-infected BMEC. Moreover, Ph-SA may be of value as an antibiotic in promoting innate immune responses by Staph. aureus-infected bovine mammary epithelial cells.
\end{abstract}

Received July 7, 2011.

Accepted October 20, 2011.

${ }^{1}$ These authors contributed equally to this work.

${ }^{2}$ Corresponding author: Jiufeng_wang@hotmail.com
Key words: bovine mastitis, cytokine, pheromonicinSA, toll-like receptor

\section{Short Communication}

Mastitis is the most costly disease in dairy cattle. It usually occurs primarily in response to intramammary bacterial infections (Zhao and Lacasse, 2008). Staphylococcus aureus is one of the most common etiological agents; it can provoke clinical mastitis but more frequently causes subclinical infections that tend to become chronic mastitis (Rainard and Riollet, 2006; Ma et al., 2007). An obvious reason for failure to cure in response to treatment is resistance of the Staph. aureus strain to the antibiotic used for treatment. Based on previous studies, rifampicin currently plays a key role in the treatment of such infections although the emergence of resistance when large numbers of bacteria are present has limited its use as a single agent (Zimmerli et al., 2004; Garrigós et al., 2011). It is therefore desirable to study new antimicrobials that could be used against Staph. aureus.

Pheromonicin-SA (Ph-SA) is an engineered, multidomain, bactericidal peptide that consists of a channelforming domain of colicin Ia fused to a Staphylococcus AgrD1 pheromone (Qiu et al., 2003). Colicin Ia is a bacterial protein toxin of 626 amino acid residues that belongs to the E1 family of colicins (Qiu et al., 1996). The E1 family of colicins comprises channel-forming bacteriocins produced by Escherichia coli, which are bactericidal only to $E$. coli and related species. Because they act on the lipid bilayer of cell membranes, colicins could be useful against bacteria that are not their natural targets if they were engineered for insertion into the inner membrane of other bacteria. Colicins kill target cells by forming a voltage-activated channel in the cell membranes (Qiu et al., 2005). Pheromones are peptides secreted by bacteria into the medium to regulate the protein production of bacteria (Qiu et al., 2003). The pheromone AgrD is an 8-residue peptide belonging 
to the $\mathrm{AgrD}$ group, is highly specific, and induces a response only in Staph. aureus strains (Zhang et al., 2004). Experiments showed that this fusion peptide has a bactericidal effect against both methicillin-sensitive and methicillin-resistant Staph. aureus, with no detectable toxicity in human liver or renal cells in culture (Qiu et al., 2003). However, to date, few data exist on the interaction between Ph-SA and bovine mammary epithelial cells (BMEC).

Bovine mammary epithelial cells are the major functional units for producing milk. The lactating mammary gland is composed of a branching network of ducts formed by epithelial cells that secrete nutrients and antibodies for the newborn calf (McManaman and Neville, 2003). Covering the inner surface of the mammary gland, BMEC form a defensive surface against bacterial infections that may ascend from the skin surface and enter the teat canal (Rainard and Riollet, 2006). They interact with invading pathogens and provide an important link between the outside environment and the interior of the body by recognizing conserved molecular patterns of invading microorganisms via pattern recognition receptors, including toll-like receptors (TLR).

The TLR family comprises phylogenetically conserved mediators of innate immunity. To date, 13 TLR family members have been identified in different organs in mammalian species (Akira et al., 2006). Among them, TLR2 is involved in the recognition of multiple products of gram-positive bacteria, and TLR4 functions as a receptor for LPS from gram-negative bacteria (Aderem and Ulevitch, 2000). Signaling via TLR may commonly lead to an activation of the transcription factors nuclear factor- $\kappa \mathrm{B}$ and the release of several proinflammatory mediators, including proinflammatory cytokines and chemokines (Akira et al., 2006). A variety of cytokines, such as IL-1 $\beta$, IL-6, and tumor necrosis factor- $\alpha$ (TNF- $\alpha$ ), has been found in healthy and infected mammary glands, and in vitro studies have shown that these cytokines are also synthesized by BMEC, as is the chemokine IL-8 (Lahouassa et al., 2007; Oviedo-Boyso et al., 2007).

Lactoferrin has been shown to be bacteriostatic for a variety of microorganisms. It works by making iron unavailable to the organisms, and may directly kill bacteria or weaken their resistance by adhesion to their surface (Chaneton et al., 2008). Its concentration in milk increases in response to infection, with the source of this increase appearing to be the mammary epithelial cells (Wellnitz and Kerr, 2004). The objective of this study was therefore to characterize innate immune responses by Staph. aureus-stimulated bovine mammary epithelial cells following treatment with $\mathrm{Ph}-\mathrm{SA}$.

A clinically healthy Holstein dairy cow at a commercial dairy herd in Beijing was selected for the study.
The cow (3 yr old and 63 to $83 \mathrm{~d}$ postpartum) was free of pathogens through 3 consecutive bacteriological examinations and with each quarter milk SCC $<200,000$ cells $/ \mathrm{mL} 10 \mathrm{~d}$ before the start of the trial. The cow was kept in an individual box stall and fed a mixed ration formulated for the dairy herd. It was milked twice daily at 0700 and $1800 \mathrm{~h}$. The use and care of the animal in this study was approved by the China Laboratory Animal Care and Use Committee.

Bovine mammary epithelial cells were isolated from the lactating cow as previously described, with slight modifications (Wellnitz and Kerr, 2004). The udder was removed and 2 pieces of the parenchyma of approximately $50 \mathrm{~g}$ each were obtained and transported to the laboratory in $500 \mathrm{~mL}$ of Dulbecco's modified Eagle's medium nutrient mixture F-12 Ham (DMEM/ F12; GIBCO, Beijing, China) containing $100 \mathrm{U} / \mathrm{mL}$ of penicillin and $100 \mu \mathrm{g} / \mathrm{mL}$ of streptomycin.

Tissue samples were minced, washed with PBS, and then incubated in a incubation mix consisting of DMEM/F12 with 10\% fetal bovine serum (FBS) containing $300 \mathrm{U} / \mathrm{mL}$ of collagenase I (Sigma, St. Louis, $\mathrm{MO})$ and $100 \mathrm{U} / \mathrm{mL}$ of hyaluronidase. The incubation proceeded for 8 to $12 \mathrm{~h}$ at $37^{\circ} \mathrm{C}$. Cells were separated from connective tissue and filtered through a $100-\mu \mathrm{m}$ mesh before being centrifuged for 5 min at 4,000 $\times \mathrm{g}$. The pellet was incubated with $0.1 \%$ of trypsin-EDTA (GIBCO, Burlington, Canada) for 5 min and centrifuged for $5 \mathrm{~min}$ at $4,000 \times \mathrm{g}$. The final pellet was resuspended in culture medium (DMEM/F12 with $10 \%$ of FBS, $1 \mathrm{~m} M$ glutamine, $5 \mathrm{mg} / \mathrm{mL}$ insulin, $500 \mathrm{ng} /$ $\mathrm{mL}$ hydrocortisone, $10 \mathrm{ng} / \mathrm{mL}$ epidermal growth factor, $20 \mathrm{ng} / \mathrm{mL}$ cholera toxin, $100 \mathrm{U} / \mathrm{mL}$ of penicillin, and $100 \mu \mathrm{g} / \mathrm{mL}$ of streptomycin) and plated in $75-\mathrm{cm}^{2}$ tissue culture flasks (Corning Inc., Corning, NY) for 24 h. To eliminate fibroblasts, cells were incubated with $0.1 \%$ of trypsin-EDTA (GIBCO, Burlington, Canada) for 7 to $8 \mathrm{~min}$ at $37^{\circ} \mathrm{C}$ and $90 \%$ humidity. Fibroblasts were decanted to separate them. The BMEC were cultured and cryopreserved at $-80^{\circ} \mathrm{C}$ in $1 \mathrm{~mL}$ of freezing medium containing 30\% FBS, 10\% dimethyl sulfoxide, and DMEM/F12. The BMEC were thawed and cultured in DMEM/F12 with $10 \%$ FBS in $25-\mathrm{cm}^{2}$ flasks at $37^{\circ} \mathrm{C}, 5 \% \mathrm{CO}_{2}$, and $90 \%$ humidity for one further passage. Next, the cells were cultured in 6 -well plates at a concentration of $3 \times 10^{5}$ cells/well to $70 \%$ confluence. Following this, the medium was replaced by DMEM/ F12 alone, and the BMEC were incubated overnight.

For bacterial treatment of epithelial cells, the Staph. aureus strain C56010 (China Veterinary Microorganism Preservation Center, Beijing, China) was incubated overnight in tryptone soy broth (TSB). A solution of Staph. aureus strain containing approximately $6 \times 10^{7}$ $\mathrm{cfu} / \mathrm{mL}$ was prepared. Concentrations of Staph. aureus 
solution were determined by densitometry followed by enumeration after agar plating of bacterial serial dilutions. Two hundred microliters of bacterial suspension $\left(6 \times 10^{7} \mathrm{cfu} / \mathrm{mL}\right)$ was added to each well of BMEC, and control cells were treated with $200 \mu \mathrm{L}$ of TSB only. After $2 \mathrm{~h}$ of coculture, cells were washed 4 times in PBS. The cells were divided into 2 groups: the Ph-SA group and the rifampicin group (3 wells per group for each experiment). The doses of $\mathrm{Ph}-\mathrm{SA}$ and rifampicin chosen were generated according to the pilot experiments. After infection, cells in the Ph-SA group were treated with Ph-SA $(8 \mu \mathrm{g} / \mathrm{mL})$, and cells in the rifampicin group were treated with rifampicin $(14 \mu \mathrm{g} / \mathrm{mL})$. The independent experiments were performed 3 times.

At $0,2,6,12$, and $24 \mathrm{~h}$ postinfection (PI), BMEC were collected and total RNA was extracted with TRIzol reagent (Invitrogen, Carlsbad, CA). For each sample, the amount of RNA extracted was determined and its purity [optical density $(\mathrm{OD})_{260} / \mathrm{OD}_{280}$ absorption ratio $>1.8$ ] was verified with a NanoDrop ND-2000C Spectrophotometer (NanoDrop Technologies Inc., Wilmington, DE) before storage at $-80^{\circ} \mathrm{C}$. Real-time PCR was performed with the SYBR Premix DimerEraser (TaKaRa Biotechnology Inc., Shiga, Japan) using an ABI 7500 Real-Time PCR System (Applied Biosystems, Foster City, CA). The primers used were adopted from a previous study (Griesbeck-Zilch et al., 2008). However, each system was re-evaluated and optimized for the current approach. To evaluate the relative quantification of mRNA expression, the cycle threshold $\left(\mathrm{C}_{\mathrm{T}}\right)$ values of the target genes were normalized against the arithmetic mean (AM) of 3 reference genes: GAPDH, ubiquitin, and tyrosine 3-monooxygenase/tryptophan 5 -monoxygenase activation protein (YWHAZ), and the results presented as $\log _{2}\left(2^{-\Delta \Delta \mathrm{CT}}\right)$ values. The relative mRNA expression of the target gene at each time point ( $\mathrm{X}$, where $\mathrm{X}=0,2,6,12$, or $24 \mathrm{~h}$ ) was calculated using the following equations:

$$
\begin{gathered}
\Delta \mathrm{C}_{\mathrm{T}}=\mathrm{C}_{\mathrm{T} \text { (target gene) }}-\mathrm{C}_{\mathrm{T} \text { (AM of reference genes) }}, \\
\Delta \Delta \mathrm{C}_{\mathrm{T}}=\Delta \mathrm{C}_{\mathrm{T} \text { (X h treated cells) }}-\Delta \mathrm{C}_{\mathrm{T} \text { (X h control cells) }} .
\end{gathered}
$$

Statistical analysis was conducted using Version 16.0 of the SPSS statistical software package (SPSS Inc., Chicago, IL). Data were analyzed by Tukey's test for multiple comparisons. A $P$-value of $<0.05$ was considered statistically significant.

In the Ph-SA group, TLR2 mRNA expression increased at $12 \mathrm{~h}(P=0.037)$ and $24 \mathrm{~h}(P=0.010) \mathrm{PI}$ (Figure 1A). In the rifampicin group, elevations were observed at $12 \mathrm{~h}(P=0.030)$ and $24 \mathrm{~h}(P=0.001)$ PI. At $24 \mathrm{~h}$ PI, TLR4 mRNA expression increased $(P$ $<0.001)$ in the Ph-SA group and was higher $(P<$
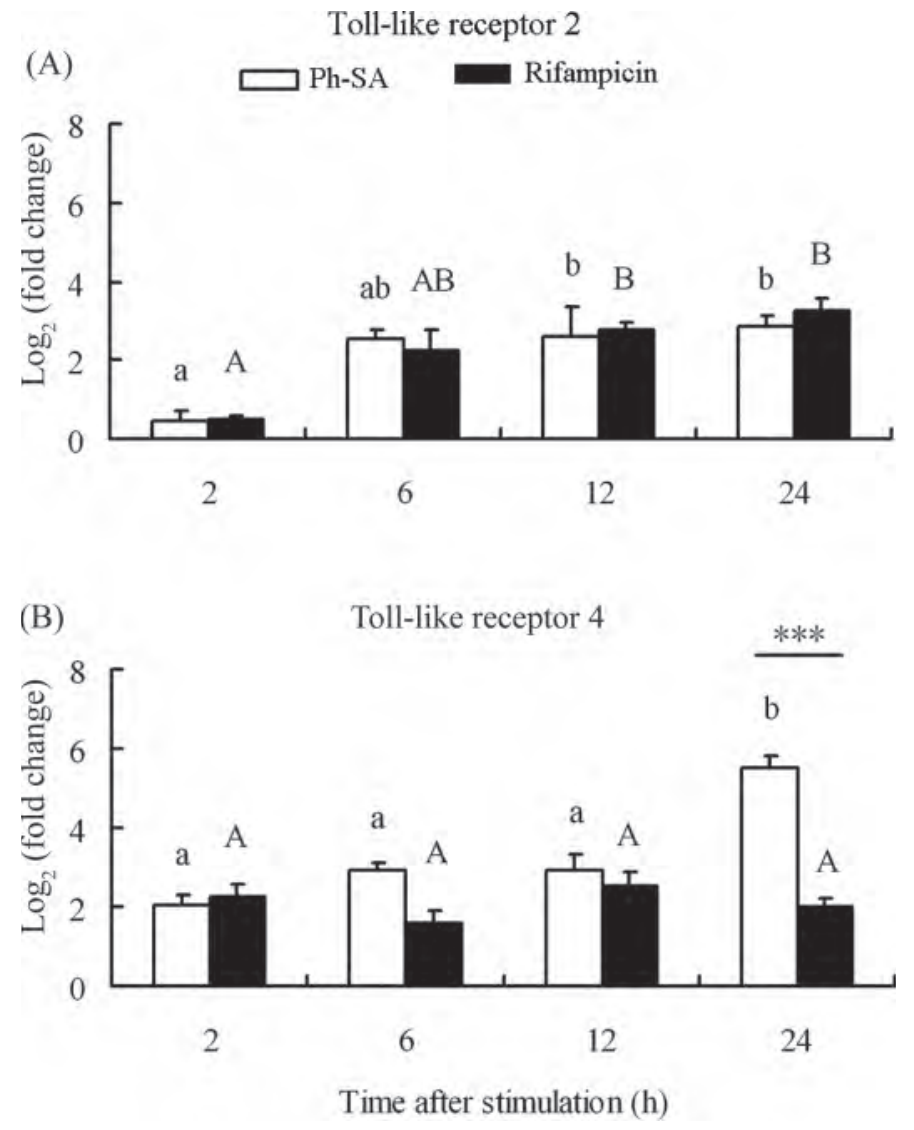

Figure 1. Toll-like receptor (TLR) 2 and TLR4 mRNA expression changes in Staphylococcus aureus-stimulated bovine mammary epithelial cells following pheromonicin-SA (Ph-SA) or rifampicin treatments. Data are expressed as means $\pm \mathrm{SD}$ of 3 independent experiments. Within the Ph-SA group, values without common lowercase letters (a, b) differ significantly $(P<0.05)$. Within the rifampicin group, values without common uppercase letters $(\mathrm{A}, \mathrm{B})$ differ significantly $(P<$ $0.05)$. Significant differences between the $\mathrm{Ph}$-SA and rifampicin groups within one measured time point are indicated by $* * *(P<0.001)$.

0.001) in the $\mathrm{Ph}-\mathrm{SA}$ group than in the rifampicin group (Figure 1B).

Interleukin-1 $\beta$ mRNA expression was elevated at $6 \mathrm{~h}$ $(P=0.003), 12 \mathrm{~h}(P=0.001)$, and $24 \mathrm{~h}(P<0.001)$ $\mathrm{PI}$ in the Ph-SA group (Figure 2A). Similarly, in the rifampicin group, increases were found at $6 \mathrm{~h}(P=$ $0.014), 12 \mathrm{~h}(P=0.008)$, and $24 \mathrm{~h}(P=0.014)$ PI. At $24 \mathrm{~h}$ PI, IL-1 $\beta$ mRNA expression was higher $(P$ $<0.001)$ in the $\mathrm{Ph}-\mathrm{SA}$ group than in the rifampicin group. Increases in TNF- $\alpha$ mRNA expression were found at $6 \mathrm{~h}(P=0.005), 12 \mathrm{~h}(P<0.001)$, and 24 h $(P<0.001)$ PI in the Ph-SA group (Figure 2B). In the rifampicin group, elevations were detected at $6 \mathrm{~h}$ $(P=0.046), 12 \mathrm{~h}(P=0.022)$, and $24 \mathrm{~h}(P=0.006)$ PI. At $24 \mathrm{~h}$ PI, TNF- $\alpha$ mRNA expression was higher $(P<0.001)$ in the $\mathrm{Ph}-\mathrm{SA}$ group than in the rifampicin group. Interleukin-6 mRNA expression increased at $6 \mathrm{~h}$ $(P=0.001), 12 \mathrm{~h}(P<0.001)$, and $24 \mathrm{~h}(P<0.001)$ 


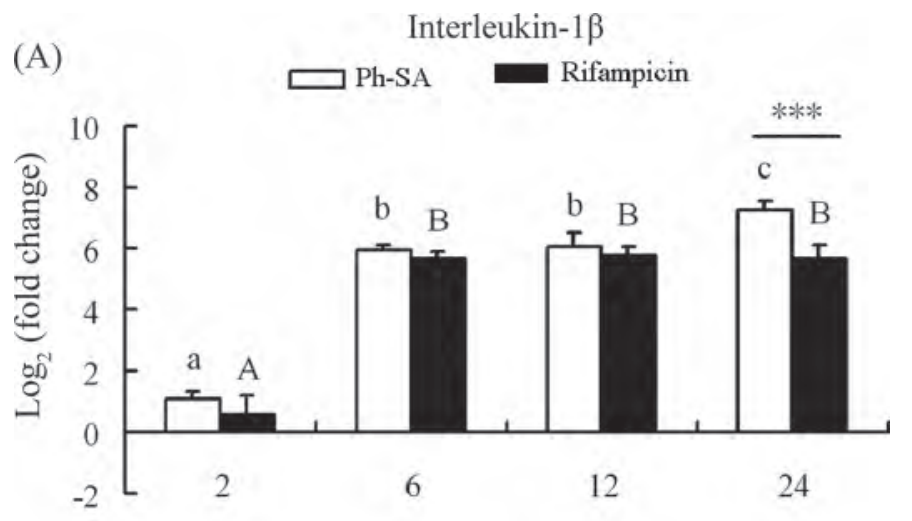

(B)

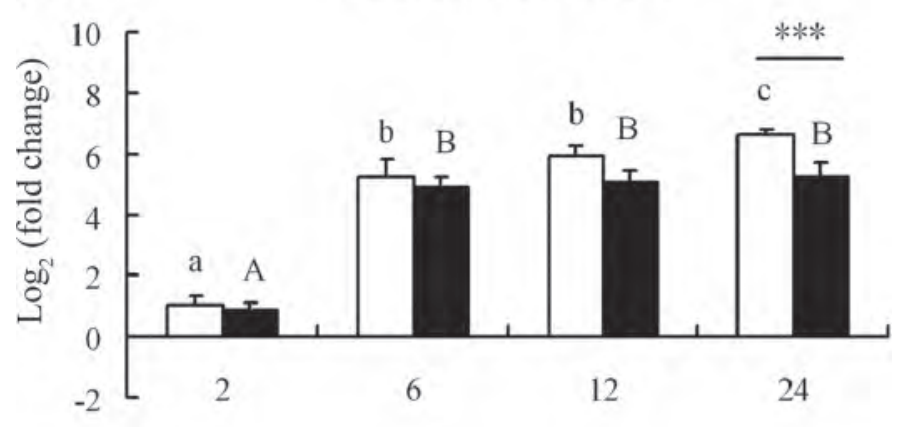

(C) Interleukin-6

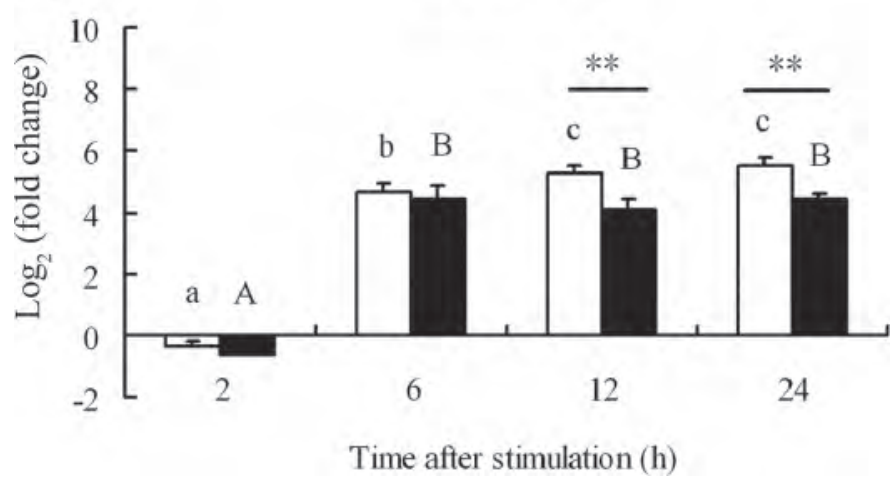

Figure 2. Interleukin-1 $\beta$, tumor necrosis factor (TNF)- $\alpha$, and IL-6 mRNA expression changes in Staphylococcus aureus-stimulated bovine mammary epithelial cells following pheromonicin-SA (Ph-SA) or rifampicin treatments. Data are expressed as means \pm SD of 3 independent experiments. Within the $\mathrm{Ph}-\mathrm{SA}$ group, values without common lowercase letters $(\mathrm{a}, \mathrm{b}, \mathrm{c})$ differ significantly $(P<0.05)$. Within the rifampicin group, values without common uppercase letters (A, B) differ significantly $(P<0.05)$. Significant differences between the $\mathrm{Ph}-\mathrm{SA}$ and rifampicin groups within one measured time point are indicated by $* *(P<0.01)$ and $* * *(P<0.001)$.

$\mathrm{PI}$ in the Ph-SA group (Figure $2 \mathrm{C}$ ). In the rifampicin group, IL-6 mRNA expression was elevated at $6 \mathrm{~h}(P=$ $0.003), 12 \mathrm{~h}(P=0.028)$, and $24 \mathrm{~h}(P=0.003) \mathrm{PI}$ and was higher in the $\mathrm{Ph}-\mathrm{SA}$ group than in the rifampicin

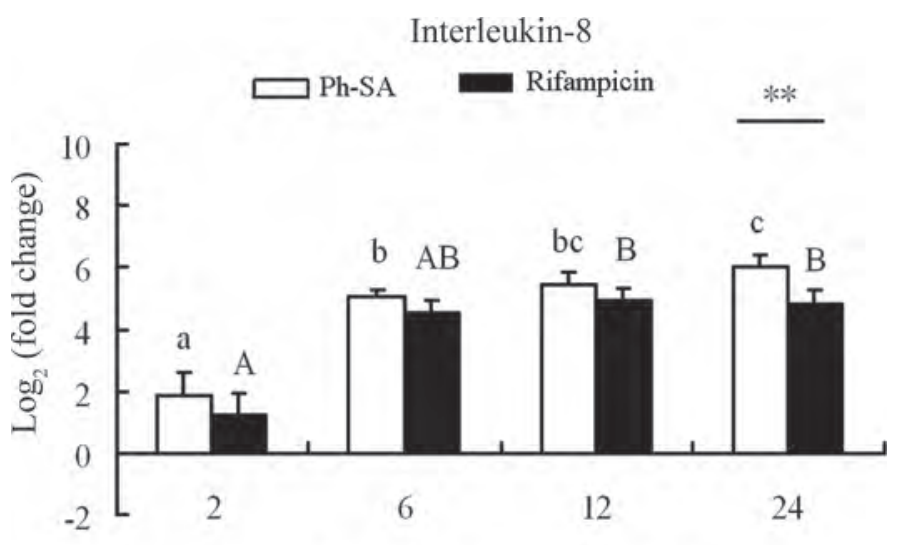

Time after stimulation (h)

Figure 3. Interleukin-8 mRNA expression changes in Staphylococcus aureus-stimulated bovine mammary epithelial cells following pheromonicin-SA (Ph-SA) or rifampicin treatments. Data are expressed as means \pm SD of 3 independent experiments. Within the Ph-SA group, values without common lowercase letters (a, b, c) differ significantly $(P<0.05)$. Within the rifampicin group, values without common uppercase letters $(A, B)$ differ significantly $(P<0.05)$. Significant differences between the $\mathrm{Ph}-\mathrm{SA}$ and rifampicin groups within one measured time point are indicated by $* *(P<0.01)$.

group at $12 \mathrm{~h}(P=0.002)$ and $24 \mathrm{~h}(P=0.001) \mathrm{PI}$. In the Ph-SA group, IL- 8 mRNA expression increased at $6 \mathrm{~h}(P=0.002), 12 \mathrm{~h}(P<0.001)$, and $24 \mathrm{~h}(P<$ $0.001)$ PI (Figure 3). Elevations were detected at $12 \mathrm{~h}$ $(P=0.020)$ and $24 \mathrm{~h}(P=0.036) \mathrm{PI}$ in the rifampicin group. At $24 \mathrm{~h} \mathrm{PI}$, IL-8 mRNA expression was higher $(P=0.002)$ in the Ph-SA group than in the rifampicin group.

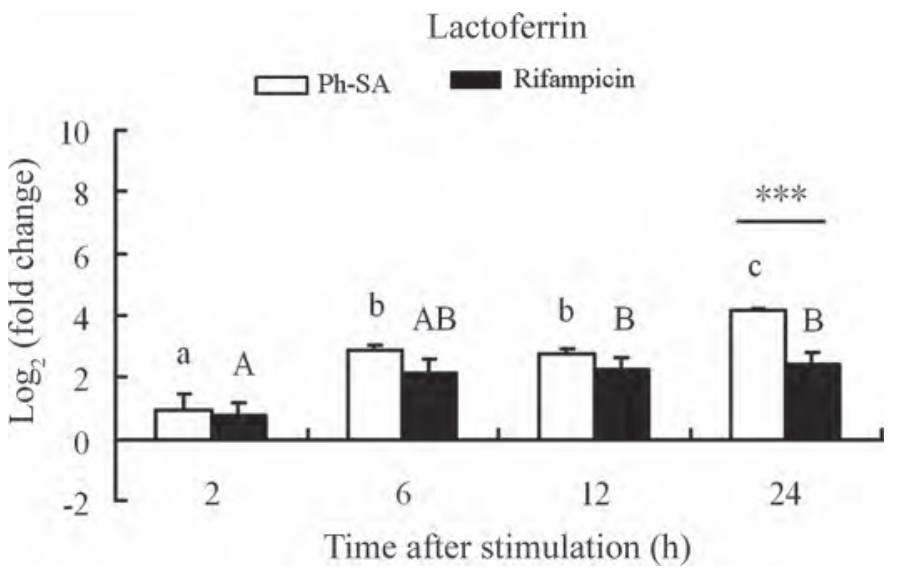

Figure 4. Lactoferrin mRNA expression changes in Staphylococcus aureus-stimulated bovine mammary epithelial cells following pheromonicin-SA (Ph-SA) or rifampicin treatments. Data are expressed as means $\pm \mathrm{SD}$ of 3 independent experiments. Within the Ph-SA group, values without common lowercase letters (a, b, c) differ significantly $(P<0.05)$. Within the rifampicin group, values without common uppercase letters $(\mathrm{A}, \mathrm{B})$ differ significantly $(P<0.05)$. Significant differences between the $\mathrm{Ph}-\mathrm{SA}$ and rifampicin groups within one measured time point are indicated by $* * *(P<0.001)$. 
In the Ph-SA group, the mRNA expression of lactoferrin increased at $6 \mathrm{~h}(P<0.001), 12 \mathrm{~h}(P=0.001)$, and $24 \mathrm{~h}(P<0.001)$ PI (Figure 4$)$. Increases were found at $12 \mathrm{~h}(P=0.032)$, and $24 \mathrm{~h}(P=0.009) \mathrm{PI}$ in the rifampicin group. At $24 \mathrm{~h} \mathrm{PI}$, lactoferrin mRNA expression was higher $(P<0.001)$ in the $\mathrm{Ph}-\mathrm{SA}$ group than in the rifampicin group.

The expression of mRNA for TLR2 and TLR4 has been found in bovine mammary tissues as well as in BMEC (Goldammer et al., 2004; Günther et al., 2011). In the rifampicin group, the increase in TLR2 mRNA expression was found but not TLR4; however, TLR4 mRNA expression was enhanced at $24 \mathrm{~h}$ PI in the PhSA group. During Staph. aureus mastitis, the TNF- $\alpha$, IL-1 $\beta$, and IL-6 produced mediate the inflammatory response at both the local and systemic levels (Oviedo-Boyso et al., 2007). We found that expression of mRNA for TNF- $\alpha$, IL-1 3 , and IL-6 was higher in Staph. aureus-infected cells treated with Ph-SA than in Staph. aureus-infected cells treated with rifampicin. The findings indicate that $\mathrm{Ph}-\mathrm{SA}$ could promote a further activation of the nuclear factor- $\kappa \mathrm{B}$ pathway.

Interleukin-8 acts as a chemokine, which attracts neutrophils and lymphocytes to the sites of inflammation, and is also involved in neutrophil activation. The present study showed that IL-8 mRNA expression was higher in Staph. aureus-infected cells treated with PhSA than in those treated with rifampicin. This might improve recruitment of target cells into the mammary gland to eliminate the invading Staph. aureus.

As a bacteriostatic and bactericidal protein, lactoferrin is able to sequester 2 molecules of iron, making them unavailable to pathogenic organisms (Chaneton et al., 2008). In the present study, we found that lactoferrin mRNA expression was higher in Staph. aureus-infected cells treated with $\mathrm{Ph}-\mathrm{SA}$ than in those treated with rifampicin. This suggests that $\mathrm{Ph}-\mathrm{SA}$ could promote lactoferrin expression, which might lead to an improvement of bacteriostatic and antiinflammatory activities.

In conclusion, our results indicate that Ph-SA could promote the expression of mRNA for TLR2, TLR4, the pro-inflammatory cytokines IL-1, IL-6, and TNF- $\alpha$, the chemotactic factor IL-8, and lactoferrin in Staph. aureus-infected BMEC. Our findings also suggest that Ph-SA may be of value as an antibiotic in promoting innate immune responses by Staph. aureus-infected bovine mammary epithelial cells.

\section{ACKNOWLEDGMENTS}

This project was supported by grants from the Program for New Century Excellent Talents in Uni- versity (China; Project No. NCET-10-0791), the National Natural Science Foundation of China (Project No. 30972232), and the Special Fund for Agro-scientific Research in the Public Interest of China (Project No. 201003060-07). We thank Olga Wellnitz (University of Bern, Switzerland) for helpful advice.

\section{REFERENCES}

Aderem, A., and R. J. Ulevitch. 2000. Toll-like receptors in the induction of the innate immune response. Nature 406:782-787.

Akira, S., S. Uematsu, and O. Takeuchi. 2006. Pathogen recognition and innate immunity. Cell 124:783-801.

Chaneton, L., L. Tirante, J. Maito, J. Chaves, and L. E. Bussmann. 2008. Relationship between milk lactoferrin and etiological agent in the mastitic bovine mammary gland. J. Dairy Sci. 91:1865-1873.

Garrigós, C., O. Murillo, G. Euba, R. Verdaguer, F. Tubau, C. Cabellos, J. Cabo, and J. Ariza. 2011. Efficacy of tigecycline alone and with rifampin in foreign-body infection by methicillin-resistant Staphylococcus aureus. J. Infect. doi:10.1016/j.jinf.2011.07.001.

Goldammer, T., H. Zerbe, A. Molenaar, H. J. Schuberth, R. M. Brunner, S. R. Kata, and H. M. Seyfert. 2004. Mastitis increases mammary mRNA abundance of beta-defensin 5, toll-like-receptor 2 (TLR2), and TLR4 but not TLR9 in cattle. Clin. Diagn. Lab. Immunol. 11:174-185.

Griesbeck-Zilch, B., H. H. Meyer, C. H. Kuhn, M. Schwerin, and O. Wellnitz. 2008. Staphylococcus aureus and Escherichia coli cause deviating expression profiles of cytokines and lactoferrin messenger ribonucleic acid in mammary epithelial cells. J. Dairy Sci. 91:2215-2224.

Günther, J., K. Esch, N. Poschadel, W. Petzl, H. Zerbe, S. Mitterhuemer, H. Blum, and H. M. Seyfert. 2011. Comparative kinetics of Escherichia coli- and Staphylococcus aureus-specific activation of key immune pathways in mammary epithelial cells demonstrates that $S$. aureus elicits a delayed response dominated by interleukin-6 (IL-6) but not by IL-1A or tumor necrosis factor alpha. Infect. Immun. 79:695-707.

Lahouassa, H., E. Moussay, P. Rainard, and C. Riollet. 2007. Differential cytokine and chemokine responses of bovine mammary epithelial cells to Staphylococcus aureus and Escherichia coli. Cytokine $38: 12-21$.

Ma, J. L., J. F. Wang, K. Wang, C. X. Wu, T. Lai, and Y. H. Zhu. 2007. Short communication: Changes in micromineral, magnesium, cytokine, and cortisol concentrations in blood of dairy goats following intramammary inoculation with Staphylococcus aureus. J. Dairy Sci. 90:4679-4683.

McManaman, J. L., and M. C. Neville. 2003. Mammary physiology and milk secretion. Adv. Drug Deliv. Rev. 55:629-641.

Oviedo-Boyso, J., J. Valdez-Alarcon, M. Cajero-Juarez, A. OchoaZarzosa, J. E. Lopez-Meza, A. Bravo-Patino, and V. M. Baizabal-Aguirre. 2007. Innate immune response of bovine mammary gland to pathogenic bacteria responsible for mastitis. J. Infect. 54:399-409.

Qiu, X. Q., K. S. Jakes, P. K. Kienker, A. Finkelstein, and S. L. Slatin. 1996. Major transmembrane movement associated with colicin Ia channel gating. J. Gen. Physiol. 107:313-328.

Qiu, X. Q., H. Wang, X. F. Lu, J. Zhang, S. F. Li, G. Cheng, L. Wan, L. Yang, J. Y. Zuo, Y. Q. Zhou, H. Y. Wang, X. Cheng, S. H. Zhang, Z. R. Ou, Z. C. Zhong, J. Q. Cheng, Y. P. Li, and G. Y. Wu. 2003. An engineered multidomain bactericidal peptide as a model for targeted antibiotics against specific bacteria. Nat. Biotechnol. 21:1480-1485.

Qiu, X. Q., J. Zhang, H. Wang, and G. Y. Wu. 2005. A novel engineered peptide, a narrow-spectrum antibiotic, is effective against vancomycin-resistant Enterococcus faecalis. Antimicrob. Agents Chemother. 49:1184-1189. 
Rainard, P., and C. Riollet. 2006. Innate immunity of the bovine mammary gland. Vet. Res. 37:369-400.

Wellnitz, O., and D. E. Kerr. 2004. Cryopreserved bovine mammary cells to model epithelial response to infection. Vet. Immunol. Immunopathol. 101:191-202

Zhang, L., J. Lin, and G. Ji. 2004. Membrane anchoring of the AgrD N-terminal amphipathic region is required for its processing to produce a quorum-sensing pheromone in Staphylococcus aureus. J. Biol. Chem. 279:19448-19456.

Zhao, X., and P. Lacasse. 2008. Mammary tissue damage during bovine mastitis: Causes and control. J. Anim. Sci. 86(Suppl. 13):57-65.

Zimmerli, W., A. Trampuz, and P. E. Ochsner. 2004. Prosthetic-joint infections. N. Engl. J. Med. 351:1645-1654. 